\title{
Stress tolerance and membrane lipid unsaturation in Saccharomyces cerevisiae grown aerobically or anaerobically
}

\author{
E. L. Steels, R. P. Learmonth and K. Watson \\ Author for correspondence: K. Watson. Tel: +61 6773 3125. Fax: +61 67728235
}

Department of Biochemistry, Microbiology and Nutrition, University of New England, Armidale 2351, Australia
Saccharomyces cerevisiae cells grown either aerobically or anaerobically were tested for tolerance to a brief heat stress $\left(52{ }^{\circ} \mathrm{C}, 5 \mathrm{~min}\right)$ or oxidative stress (20 $\mathrm{mM} \mathrm{H} \mathrm{O}_{2}, 15 \mathrm{~min}$ ). Tolerance was related to growth phase, in that stationary phase cells were intrinsically more resistant to heat or oxidative stress than exponential phase cells. A mild heat shock ( $37^{\circ} \mathrm{C}, 30 \mathrm{~min}$ ) induced thermotolerance and oxidative tolerance in both aerobic and anaerobic cells. However, prior exposure to a low concentration of $\mathrm{H}_{2} \mathrm{O}_{2}(0.1 \mathrm{mM}, 60 \mathrm{~min})$ induced protection against the lethal concentration of $\mathrm{H}_{2} \mathrm{O}_{2}$ but not against the lethal temperature. Sensitivity to both heat and oxidative stress was dependent on membrane lipid composition. In the case of anaerobic cells, the most stress resistant had membranes enriched in saturated fatty acids, followed in order by cells enriched in oleic and linolenic acids. Aerobic cells with membranes enriched in palmitoleic and oleic acids showed the highest resistance to stress under all conditions. In both aerobic and anaerobic cells, a mild heat shock or oxidative shock induced markedly increased levels of thiobarbituric acid reactive substance (TBARS), indicative of malondialdehyde formation and lipid damage. Anaerobic cells with membranes enriched in linolenic acid had the highest TBARS, followed by cells enriched in oleic acid, with cells enriched in saturated fatty acids showing the lowest TBARS. The results suggest that heat and oxidative stress may share a common mechanism of damage through induction of oxygen-derived free radicals, resulting in membrane lipid damage. The extent of cellular damage was related to membrane lipid composition and correlated positively with increasing unsaturation of the phospholipid fatty acyl component.

Keywords: Saccharomyces cerevisiae, stress tolerance, membrane lipids, free radicals

\section{INTRODUCTION}

All living cells are subject to oxygen toxicity. The main oxygen-derived species causing damage are thought to be hydrogen peroxide, the superoxide anion $\left(\mathrm{O}_{2}^{-}\right)$and the highly reactive hydroxyl $\left(\mathrm{OH}^{\cdot}\right)$ radical. These species are formed during normal cell metabolism, changes in oxygen tension or by redox reactions (Halliwell \& Gutteridge, 1989). Biological systems susceptible to attack by oxygen species include DNA, proteins and lipids (Sies, 1986). Membrane phospholipids are particularly susceptible to oxygen-derived free radical attack due to the abundance of polyunsaturated fatty acids and high solubility of molecular oxygen in hydrophobic membranes relative to aqueous environments (Halliwell \& Gutteridge, 1989).

In microbial systems, oxidative damage has been most intensively studied in the enteric bacteria Escherichia coli and Salmonella typhimurium (for a review, see Farr \& Kogoma, 1991) and, in the case of eukaryotic microorganisms, Saccharomyces cerevisiae and Neurospora crassa (for a review, see Watson, 1990).

We have used yeast cells to study the interrelationships between oxidative and other stresses, particularly heat. The yeast cell provides an attractive model system for oxidative stress, not only because of rapid growth and relative genetic simplicity compared to higher organisms, but also because cellular composition and function may be readily manipulated by altering environmental conditions. 
Our experimental system offers distinct advantages over previous systems which have been used for studies on oxidative stress. These include the controlled manipulation of membrane lipid unsaturation. The latter parameter is thought to be an important factor governing lipid peroxidation damage of biological membranes by oxygen-derived free radicals. Furthermore, yeasts can grow both aerobically and anaerobically, and thus a comparison of how cells cope with oxidative stress in aerobic and anaerobic environments may be directly tested in the same organism.

In this paper, we describe the response of aerobic and anaerobic $S$. cerevisiae cells with different membrane lipid compositions to oxidative stress, induced by $\mathrm{H}_{2} \mathrm{O}_{2}$, and temperature shifts. A mild heat shock was found to induce tolerance against a lethal temperature and $\mathrm{H}_{2} \mathrm{O}_{2}$ challenge. However, pretreatment with low levels of $\mathrm{H}_{2} \mathrm{O}_{2}$ induced tolerance against a lethal $\mathrm{H}_{2} \mathrm{O}_{2}$ challenge but not a lethal temperature challenge.

\section{METHODS}

Growth conditions. Saccharomyces cerevisiae strain K7 (ATCC 26422) was used. Cell were grown aerobically at $25^{\circ} \mathrm{C}$ in an orbital shaker (150 r.p.m.) in medium containing (per litre): $10 \mathrm{~g}$ yeast extract (Oxoid), $5 \mathrm{~g}$ bacteriological peptone (Oxoid), $3 \mathrm{~g} \mathrm{KH} \mathrm{KO}_{4}, 3 \mathrm{~g}\left(\mathrm{NH}_{4}\right)_{2} \mathrm{SO}_{4}, 25 \mathrm{mg} \mathrm{CaCl}{ }_{2} .2 \mathrm{H}_{2} \mathrm{O}, 25 \mathrm{mg}$ $\mathrm{MgSO}_{4} \cdot 7 \mathrm{H}_{2} \mathrm{O}$ and $20 \mathrm{~g}$ glucose, $\mathrm{pH} 7.5$ (YEP medium). Anaerobic growth was in YEP medium as previously described (Watson \& Rose, 1980) with a constant stream of high-purity nitrogen gas passing through the medium. Lipid supplements, when provided, were as ergosterol $\left(5 \mathrm{mg} \mathrm{l}^{-1}\right)$ and either oleic $\left(30 \mathrm{mg} \mathrm{l}^{-1}\right)$, linoleic $\left(30 \mathrm{mg} \mathrm{l}^{-1}\right)$ or linolenic $\left(30 \mathrm{mg} \mathrm{l}^{-1}\right)$ acids. Lipid analysis, as presented in Results, confirmed the aerobic and anaerobic environments of these growth conditions (for a review, see Watson, 1984). Cells grown anaerobically without lipid supplements showed a low content, generally less than $10 \%$, of monounsaturated fatty acids. On the other hand, cells grown anaerobically with lipid supplements were typically enriched in the fatty acid supplement (Watson \& Rose, 1980). Cells grown aerobically under our conditions were enriched in monounsaturated fatty acids with a composition characteristic of aerobic S. cerevisiae (Watson, 1984).

Lipid analysis. Lipids were extracted as previously described (Watson \& Rose, 1980). Total phospholipids were separated from neutral lipids by TLC using silica gel G plates (Merck; $0.25 \mathrm{~mm}$ thick) and a solvent system of light petroleum (b.p. $\left.40-60^{\circ} \mathrm{C}\right) /$ diethyl ether/acetic acid $(68: 29: 2$, by vol.). The phospholipids, which remained at the origin, were scraped off the plates and methylated with $\mathrm{BF}_{3} /$ methanol at $80^{\circ} \mathrm{C}$ for $30 \mathrm{~min}$.

The fatty acid methyl esters were extracted into hexane and concentrated to a small volume prior to analysis. Samples were analysed using a Hewlett-Packard model 5890A gas chromatograph equipped with a flame ionization detector. Conditions were as follows: $2 \mathrm{~m}$ glass $10 \%$ Silar 10C column (Applied Sciences), carrier gas (nitrogen) flow rate $30 \mathrm{ml} \mathrm{min}^{-1}$, detector and injection temperature $200^{\circ} \mathrm{C}$ and oven temperature $180^{\circ} \mathrm{C}$. Fatty acid methyl esters were identified from their retention times relative to appropriate standards (Sigma), and percentage fatty acid composition was determined using the Delta chromatography data system (Digital Systems).
Thiobarbituric acid reactive substance (TBARS). TBARS was estimated as outlined by Jain (1988) and modified for yeast cells as follows. Cells were pelleted at $2000 \mathrm{~g}$ for $2 \mathrm{~min}$ and the pellet was washed twice with distilled Millipore purified $\mathrm{H}_{2} \mathrm{O}$. Washed cells were disrupted by vortexing for six periods of $20 \mathrm{~s}$ each with an equal volume of glass beads $(0.5 \mathrm{~mm}$ diameter $)$ in phosphate-buffered saline and $10 \%(\mathrm{w} / \mathrm{v})$ trichloroacetic acid. Cells were kept on ice, except during vortex mixing. Extracts were centrifuged at $2000 \mathrm{~g}$ for $3 \mathrm{~min}$ and the supernatant mixed with $0.1 \mathrm{ml} 0.1 \mathrm{M}$ EDTA and $0.6 \mathrm{ml} 1 \%(\mathrm{w} / \mathrm{v})$ thiobarbituric acid in $0.05 \mathrm{M} \mathrm{NaOH}$. The reaction mixture was incubated in a boiling waterbath for $15 \mathrm{~min}$ and, after cooling, the $A_{532}$ was measured. Results were expressed as $\mu \mathrm{mol}$ malondialdehyde per mg protein.

Studies on the heat-shock response. Cells were grown at $25^{\circ} \mathrm{C}$ in batch culture and, at various times of the groth phase, were heat shocked at $37^{\circ} \mathrm{C}$ for $30 \mathrm{~min}$. For heat-stress experiments, cells were rapidly heated to $52{ }^{\circ} \mathrm{C}$ for $5 \mathrm{~min}$ following heat shock $\left(37^{\circ} \mathrm{C}\right.$ for $30 \mathrm{~min}$, heated directly to $52{ }^{\circ} \mathrm{C}$ - induced thermotolerance) or, alternatively, cells at $25^{\circ} \mathrm{C}$ were rapidly heated directly to $52^{\circ} \mathrm{C}$ for $5 \mathrm{~min}$ (intrinsic thermotolerance). Following heat stress, cells were cooled to $25^{\circ} \mathrm{C}$ in an ice bath before plating onto YEP media for viability measurements. Viable cells were determined after incubation at $28^{\circ} \mathrm{C}$ for $2-3 \mathrm{~d}$.

Studies on $\mathrm{H}_{2} \mathrm{O}_{2}$ tolerance. Preliminary experiments were performed to determine appropriate concentrations of $\mathrm{H}_{2} \mathrm{O}_{2}$ for lethal and sublethal stresses, as detailed in Results. In later experiments for $\mathrm{H}_{2} \mathrm{O}_{2}$ shock, cells were incubated with $0.1 \mathrm{mM}$ $\mathrm{H}_{2} \mathrm{O}_{2}$ for 30 min and then washed in fresh medium or subjected to $\mathrm{H}_{2} \mathrm{O}_{2}$ stress. For $\mathrm{H}_{2} \mathrm{O}_{2}$ stress, cells were incubated with $20 \mathrm{mM} \mathrm{H} \mathrm{O}_{2}$ for $15 \mathrm{~min}$ and then washed in fresh medium. Viable cells were determined as above.

Cell protein. Protein content was assayed by a modification of the Bradford procedure (Bradford, 1976) using the Coomassie blue microassay method (Pierce). BSA was used as a standard.

\section{RESULTS}

\section{Membrane fatty acid composition}

The percentage fatty acid composition of phospholipids from cells grown aerobically or anaerobically with lipid supplements is presented in Fig. 1. Aerobic cells in the exponential growth phase contained about $80 \%$ monounsaturated fatty acids, consisting of $40 \%$ palmitoleic $\left(C_{16: 1}\right)$ and $38 \%$ oleic $\left(C_{18: 1}\right)$ acids. There was little change in percentage unsaturated fatty acid as cells grew into the stationary growth phase.

In cells grown anaerobically without lipid supplements, the phospholipids were typically enriched in saturated fatty acids $(90 \%)$ and low in monounsaturated fatty acids $(10 \%)$. The phospholipids of lipid-supplemented anaerobically grown cells were typically enriched in the fatty acid growth supplement. In cells in the exponential growth phase, membranes were enriched to more than $60 \%$ in $\mathrm{C}_{18: 1}$ supplement or linoleic acid $\left(\mathrm{C}_{18: 2}\right)$ supplement and about $70 \%$ in linolenic acid $\left(\mathrm{C}_{18: 3}\right)$ supplement growth media. Saturated fatty acids, mainly $\mathrm{C}_{16: 0}$ palmitic acid, constituted $30-35 \%$ of the total. In contrast, phospholipids from cells in stationary growth phase were considerably lower in the lipid supplements, typically a 40-50\% enrichment (results not shown). A corresponding increase in saturated fatty acid, particularly $\mathrm{C}_{16: 0}$ and 


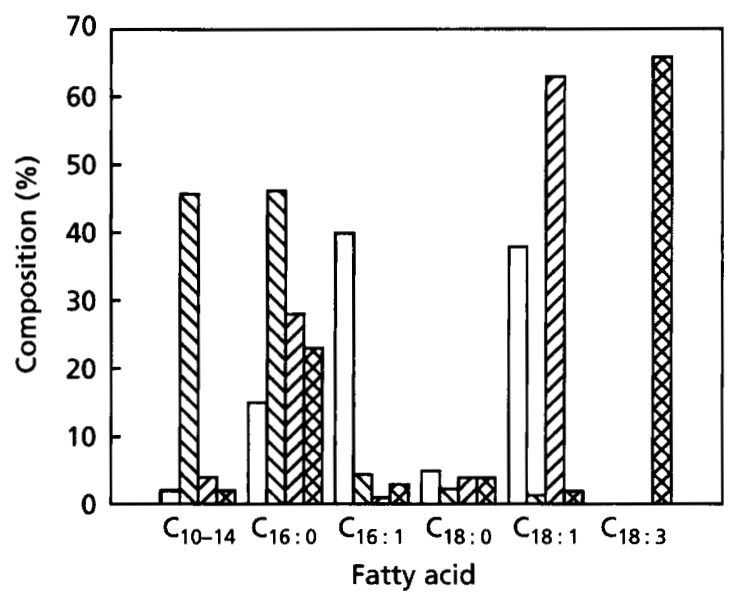

Fig. 1. Fatty acid composition of phospholipids from exponential phase cells. $\square$, Aerobic; $\Delta$, anaerobic unsupplemented; $\square$, anaerobic with $C_{18: 1}$ supplement; $\otimes$, anaerobic with $C_{18: 3}$ supplement. The data shown are from a representative experiment.
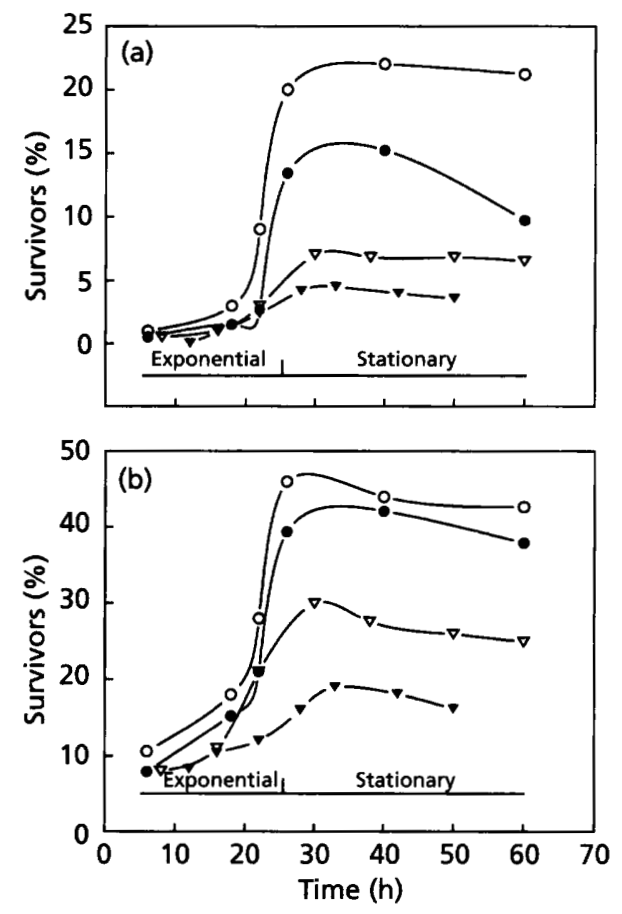

Fig. 2. Intrinsic and induced thermotolerance of cells in relation to culture time. The growth phase of cells treated at each time is shown on the figure. (a) Intrinsic thermotolerance was measured by heating from $25^{\circ} \mathrm{C}$ to $52^{\circ} \mathrm{C}$ for $5 \mathrm{~min}$. (b) Induced thermotolerance was measured by heating from $25^{\circ} \mathrm{C}$ to $37^{\circ} \mathrm{C}$ for $30 \mathrm{~min}$ and then $52^{\circ} \mathrm{C}$ for $5 \mathrm{~min}$. $\mathrm{O}$, Aerobic; 0 , anaerobic unsupplemented; $\nabla$, anaerobic with $C_{18: 1}$ supplement; $\nabla$, anaerobic with $C_{18: 3}$ supplement. The data shown are from a representative experiment.

short-chain $\left(\mathrm{C}_{10}-\mathrm{C}_{14}\right)$ fatty acids, was noted. Anaerobically grown cells were typically low in $C_{16: 1}$, the major monounsaturated fatty acid of aerobic $S$. cerevisiae.

\section{Thermotolerance}

Intrinsic and heat-shock-induced thermotolerance was tested at selected points throughout the growth cycle of the yeast. In aerobic cells, intrinsic thermotolerance, measured as percentage cell survival after a challenge at $52{ }^{\circ} \mathrm{C}$ for $5 \mathrm{~min}$, was extremely low in exponential phase cells (Fig. 2a). As the culture approached mid to late exponential growth, there was a progressive increase in intrinsic thermotolerance, which peaked at about $20 \%$ survival at early stationary phase.

Heat-shock-induced thermotolerance, defined as a $37{ }^{\circ} \mathrm{C}$ heat shock for $30 \mathrm{~min}$ followed by a challenge at $52^{\circ} \mathrm{C}$ for $5 \mathrm{~min}$, showed a similar pattern with respect to the growth curve (Fig. 2b). However, heat-shock-induced thermotolerance was always higher than intrinsic thermotolerance of cells from the same culture, with a maximum $40-50 \%$ cell survival at late exponential growth phase.

Anaerobically grown cells showed the same pattern of increased intrinsic and acquired thermotolerance as cultures progressed from early exponential to late stationary growth phase. A trend may be noted that for both intrinsic and induced thermotolerance, aerobic cells were the most resistant, followed in decreasing order by anaerobic unsupplemented, anaerobic $C_{18: 1}$ enriched and anaerobic $\mathrm{C}_{18: 3}$ enriched cells. Maximum induced thermotolerance was roughly $40 \%$ in anaerobic unsupplemented cells, $30 \%$ in $C_{18: 1}$ cells and $20 \%$ in $C_{18: 3}$ cells, as compared to about $45 \%$ in aerobic cells. Cells enriched in $\mathrm{C}_{18: 2}$ showed between $20-30 \%$ survival (data not shown).

\section{$\mathrm{H}_{2} \mathrm{O}_{2}$ tolerance}

The effect of different concentrations (1-50 mM) of $\mathrm{H}_{2} \mathrm{O}_{2}$ on cell survival was tested in exponential (Fig. 3a) and stationary phase cells (data not shown). As shown in Fig. 3 (a) for cells in the exponential growth phase, there were marked differences in cell survival at $\mathrm{H}_{2} \mathrm{O}_{2}$ concentrations from $1-10 \mathrm{mM}$.

As found for intrinsic and induced thermotolerance, aerobic cells were the most resistant, followed in order by $\mathrm{C}_{18: 1}$ and $\mathrm{C}_{18: 3}$ anaerobic cells. At and beyond $20 \mathrm{mM}$ $\mathrm{H}_{2} \mathrm{O}_{2}$, all three cell types showed low percentage survival. The time-course of incubation of cells in the exponential phase with $10 \mathrm{mM} \mathrm{H} \mathrm{H}_{2} \mathrm{O}_{2}$ clearly demonstrated differences in sensitivity to $\mathrm{H}_{2} \mathrm{O}_{2}$ (Fig. $3 \mathrm{~b}$ ). Differences were most noticeable after $15 \mathrm{~min}$ and $30 \mathrm{~min}$ incubation with $\mathrm{H}_{2} \mathrm{O}_{2}$, with aerobic cells showing $60 \%$ and $35 \%$ viability, respectively, as compared to $35 \%$ and $<5 \%$ viability with $\mathrm{C}_{18: 3}$ cells. Differences in sensitivity to $\mathrm{H}_{2} \mathrm{O}_{2}$ were not as marked in cells in stationary growth phase. For example, at $10 \mathrm{mM} \mathrm{H}_{2} \mathrm{O}_{2}$, the percentage survival rates were approximately $60 \%, 70 \%$ and $75 \%$ for $C_{18: 3}, C_{18: 1}$ and aerobic cells, respectively.

Tolerance to $20 \mathrm{mM} \mathrm{H} \mathrm{H}_{2} \mathrm{O}_{2}$ could be induced in exponential phase cells by a prior incubation with low levels of $\mathrm{H}_{2} \mathrm{O}_{2}$ (Fig. 4). Maximum induced tolerance (approaching $60 \%$ survival) to $20 \mathrm{mM} \mathrm{H}_{2} \mathrm{O}_{2}$ was observed by pretreatment of cells with $0.1 \mathrm{mM} \mathrm{H}_{2} \mathrm{O}_{2}$. Exposure of cells to 

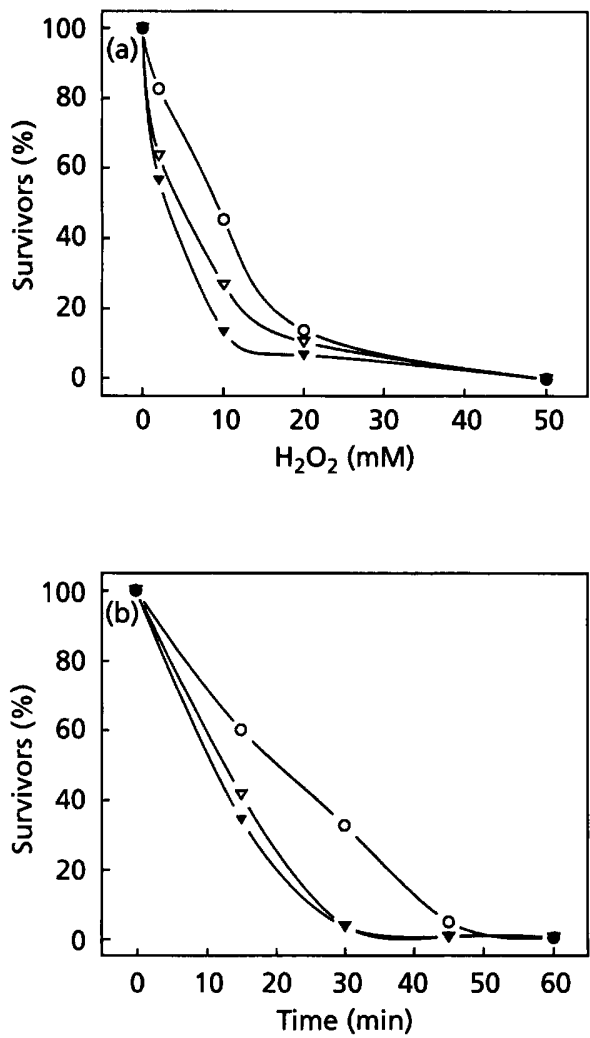

Fig. 3. Effect of $\mathrm{H}_{2} \mathrm{O}_{2}$ on survival of exponential phase cells. (a) Cells incubated with $\mathrm{H}_{2} \mathrm{O}_{2}$ for $15 \mathrm{~min}$, washed with fresh medium and cell survival determined by plate counts. (b) Timecourse of survival in $10 \mathrm{mM} \mathrm{H}_{2} \mathrm{O}_{2}$. $O$. Aerobic; $\nabla$, anaerobic with $C_{18: 1}$ supplement; $\nabla$, anaerobic with $C_{18: 3}$ supplement. The data shown are from a representative experiment.

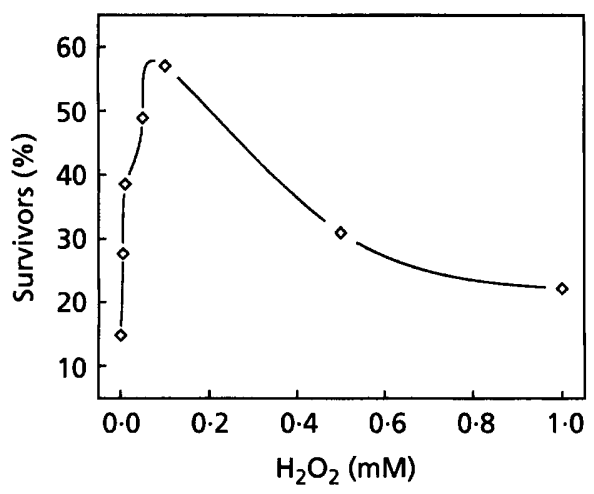

Fig. 4. Induction of $\mathrm{H}_{2} \mathrm{O}_{2}$ tolerance in aerobically grown cells in exponential growth phase. Cells were pretreated with various concentrations of $\mathrm{H}_{2} \mathrm{O}_{2}$ (as indicated on the abscissa) for $30 \mathrm{~min}$, prior to exposure to $20 \mathrm{mM} \mathrm{H}_{2} \mathrm{O}_{2}$ for $15 \mathrm{~min}$. The data shown are from a representative experiment.

lower or higher levels of $\mathrm{H}_{2} \mathrm{O}_{2}$ was less effective in inducing tolerance to $20 \mathrm{mM} \mathrm{H}_{2} \mathrm{O}_{2}$.

The results for intrinsic (Fig. 5a) and induced (Fig. 5b)
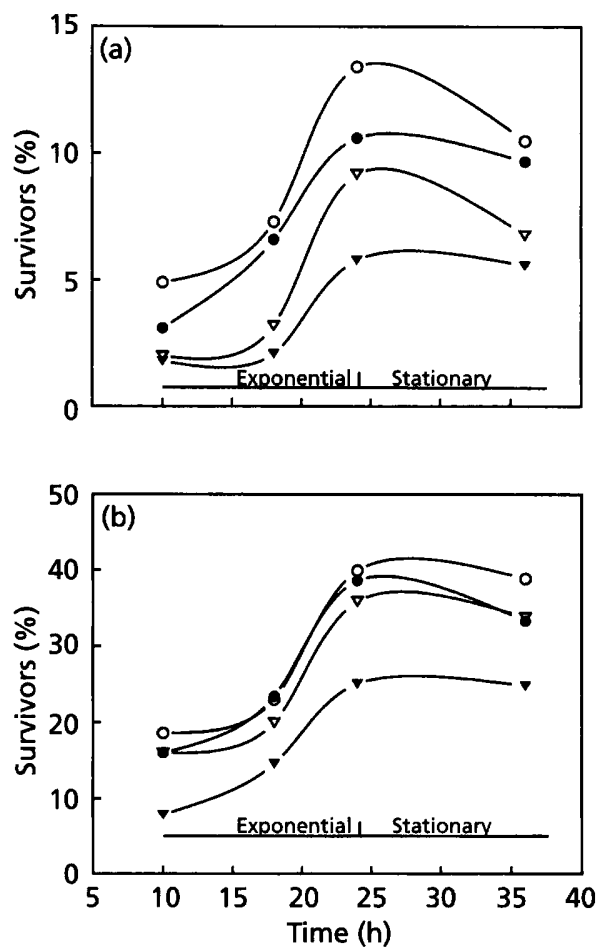

Fig. 5. Intrinsic and induced tolerance to $\mathrm{H}_{2} \mathrm{O}_{2}$ in aerobic and anaerobic cells. The growth phase of cells treated at each time is shown on the figure. (a) Intrinsic tolerance was measured by incubating cells with $20 \mathrm{mM} \mathrm{H}_{2} \mathrm{O}_{2}$ for $15 \mathrm{~min}$. (b) Induced tolerance was measured by prior incubation with $0.1 \mathrm{mM} \mathrm{H}_{2} \mathrm{O}_{2}$ for $30 \mathrm{~min}$ prior to treatment with $20 \mathrm{mM} \mathrm{H}_{2} \mathrm{O}_{2}$ for $15 \mathrm{~min}$. $O$, Aerobic; 0 , anaerobic unsupplemented; $\nabla$, anaerobic with $C_{18: 1}$ supplement; $\nabla$, anaerobic with $C_{18: 3}$ supplement.

tolerance to $\mathrm{H}_{2} \mathrm{O}_{2}$ in aerobic and anaerobic cells indicated that maximum tolerance occurred in cells towards the end of exponential and early stationary growth phase, with aerobic cells the most resistant, followed in order by anaerobic unsupplemented, $\mathrm{C}_{18: 1^{-}}$enriched and $\mathrm{C}_{18: 3^{-}}$ enriched cells.

\section{Cross-tolerance}

The response of cells to heat and $\mathrm{H}_{2} \mathrm{O}_{2}$ stress appeared to have similar kinetics, and experiments were therefore conducted to determine the degree of cross-tolerance to the two stresses. Resistance to $20 \mathrm{mM} \mathrm{H}_{2} \mathrm{O}_{2}$ could be induced by a prior heat shock at $37^{\circ} \mathrm{C}$ for $30 \mathrm{~min}$ in aerobic (Fig. 6) and anaerobic cells (data not shown). Induced tolerance in aerobic cells was generally about fourfold higher than intrinsic tolerance and about threefold higher in anaerobic cells. It was noteworthy that prior exposure of cells to low levels of $\mathrm{H}_{2} \mathrm{O}_{2}$ for $30 \mathrm{~min}$ did not induce tolerance to heat stress $\left(52^{\circ} \mathrm{C}\right.$ for $5 \mathrm{~min}$; data not shown).

\section{TBARS}

Cells in the exponential growth phase were subjected to $\mathrm{H}_{2} \mathrm{O}_{2}$ stress ( $20 \mathrm{mM}$ for $15 \mathrm{~min}$ ), and TBARS (expressed as $\mu \mathrm{mol}$ malondialdehyde per $\mathrm{mg}$ protein) was measured 
Table 1. TBARS induced by $\mathrm{H}_{2} \mathrm{O}_{2}$ in exponential phase cells

Data are the means of duplicates from a representative experiment.

\begin{tabular}{|c|c|c|c|c|}
\hline \multicolumn{3}{|l|}{$\begin{array}{l}\text { Mode of St } \\
\text { growth }\end{array}$} & \multirow{2}{*}{ 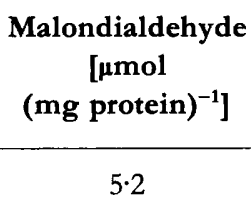 } & \multirow{2}{*}{$\begin{array}{c}\begin{array}{c}\text { Survival } \\
(\%)\end{array} \\
100\end{array}$} \\
\hline Aerobic & None & - & & \\
\hline & & + & $9 \cdot 7$ & 20 \\
\hline \multirow[t]{2}{*}{ Anaerobic } & None & - & $3 \cdot 9$ & 100 \\
\hline & & + & $13 \cdot 4$ & 16 \\
\hline \multirow[t]{2}{*}{ Anaerobic } & $C_{18: 1}$ & - & $3 \cdot 2$ & 100 \\
\hline & & + & $17 \cdot 7$ & $9 \cdot 6$ \\
\hline \multirow[t]{2}{*}{ Anaerobic } & $C_{18: 3}$ & - & $3 \cdot 9$ & 100 \\
\hline & & + & $26 \cdot 3$ & 6.8 \\
\hline
\end{tabular}

* See Methods for details.

† Cells incubated with $20 \mathrm{mM} \mathrm{H}_{2} \mathrm{O}_{2}$ for $15 \mathrm{~min}$.

in control and oxidatively stressed cells (Table 1). In aerobic cells, there was a twofold elevation of TBARS following a $\mathrm{H}_{2} \mathrm{O}_{2}$ stress. Anaerobic cells grown in medium without lipid supplements showed a threefold increase in TBARS. In the case of anaerobic cells supplemented with $\mathrm{C}_{18: 1}$ fatty acid there was a $5 \cdot 5$-fold increase and with $\mathrm{C}_{18: 3}$ fatty acid a 6.5 -fold increase (Table 1). There was a positive correlation between the amount of TBARS produced and the percentage cell survival following $\mathrm{H}_{2} \mathrm{O}_{2}$ stress. Similarly, cells subjected to a heat stress $\left(52{ }^{\circ} \mathrm{C}\right.$ for $5 \mathrm{~min}$ ) showed a marked increase in TBARS and a decrease in percentage cell survival (Table

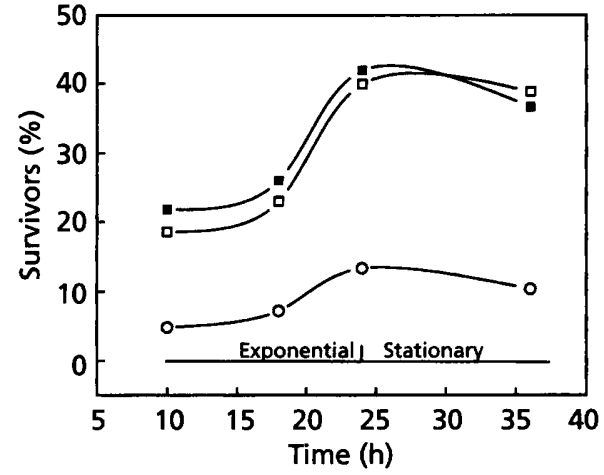

Fig. 6. Induction of tolerance to $20 \mathrm{mM} \mathrm{H}_{2} \mathrm{O}_{2}\left(15 \mathrm{~min}\right.$ ) by $\mathrm{H}_{2} \mathrm{O}_{2}$ and heat shock in aerobic cells. The growth phase of cells treated at each time is shown on the figure. Heat shock was produced by heating cells from $25^{\circ} \mathrm{C}$ to $37^{\circ} \mathrm{C}(30 \mathrm{~min})$ and $\mathrm{H}_{2} \mathrm{O}_{2}$ shock was produced by treating cells with $0.1 \mathrm{mM} \mathrm{H}_{2} \mathrm{O}_{2}$ (30 min). $\bigcirc$, Intrinsic tolerance; $\square$, induced tolerance after $\mathrm{H}_{2} \mathrm{O}_{2}$ shock; $\mathrm{D}$, induced tolerance after heat shock.

2). Furthermore, prior exposure of cells to a mild oxidative $\left(0.1 \mathrm{mM} \mathrm{H}_{2} \mathrm{O}_{2}\right.$ for $\left.30 \mathrm{~min}\right)$ or heat $\left(37^{\circ} \mathrm{C}\right.$ for $\left.30 \mathrm{~min}\right)$ shock followed by a higher stress also resulted in a marked increase in levels of TBARS. These pretreatment experiments characteristically induced an increase in cell survival compared to untreated controls (Table 2).

\section{DISCUSSION}

Oxygen is obligatory for all forms of aerobic life. Paradoxically, all living cells are subject to oxygen toxicity. Oxygen-derived species have been implicated as

Table 2. TBARS induced by $\mathrm{H}_{2} \mathrm{O}_{2}$ and heat challenge in exponential phase cells

Data are the means of duplicates from a representative experiment.

\begin{tabular}{|c|c|c|c|c|}
\hline & \multicolumn{2}{|c|}{$\mathrm{H}_{2} \mathrm{O}_{2}$} & \multicolumn{2}{|c|}{ Heat } \\
\hline & $\begin{array}{c}\text { Malondialdehyde } \\
{\left[\mu \mathrm{mol}(\mathrm{mg} \text { protein })^{-1}\right]}\end{array}$ & $\begin{array}{l}\text { Survival } \\
(\%)\end{array}$ & $\begin{array}{c}\text { Malondialdehyde } \\
{\left[\mu \mathrm{mol}(\mathrm{mg} \text { protein })^{-1}\right]}\end{array}$ & $\begin{array}{l}\text { Survival } \\
(\%)\end{array}$ \\
\hline \multicolumn{5}{|c|}{ Cells grown aerobically } \\
\hline Control & 3.8 & 100 & $6 \cdot 1$ & 100 \\
\hline Shock* & $7 \cdot 9$ & 89 & $8 \cdot 3$ & 95 \\
\hline Stresst & $15 \cdot 2$ & 11 & $16 \cdot 2$ & 9 \\
\hline Shock, stress & $16 \cdot 1$ & 53 & $16 \cdot 8$ & 47 \\
\hline \multicolumn{5}{|c|}{ Cells grown anaerobically $\ddagger$} \\
\hline Control & $5 \cdot 1$ & 100 & $5 \cdot 0$ & 100 \\
\hline Shock & $10 \cdot 5$ & 76 & $8 \cdot 5$ & 93 \\
\hline Stress & 26.9 & 5 & $20 \cdot 0$ & 2 \\
\hline Shock, stress & $28 \cdot 4$ & 30 & $22 \cdot 6$ & 28 \\
\hline
\end{tabular}

* $0.1 \mathrm{mM} \mathrm{H} \mathrm{O}_{2}$ for $30 \mathrm{~min}$ or $37^{\circ} \mathrm{C}$ for $30 \mathrm{~min}$ (heat).

$+20 \mathrm{mM} \mathrm{H}_{2} \mathrm{O}_{2}$ for $15 \mathrm{~min}$ or $52^{\circ} \mathrm{C}$ for $5 \mathrm{~min}$ (heat).

$\ddagger$ Anaerobically grown cells were enriched in $\mathrm{C}_{18: 3}$ fatty acid. 
key causative agents of ageing, tumour promotion, cancer, inflammatory-immune injury, radiation damage and other clinical disorders (Halliwell, 1987; Halliwell \& Grootveld, 1987).

In prokaryotic micro-organisms, cellular responses to oxidative stress have been primarily focused on Eschericbia coli and Salmonella typhimurium (Farr \& Kogoma, 1991). Ames and co-workers (Bochner et al., 1984; Lee et al., 1983) made the early suggestion that adenylated nucleotides or alarmones may be the common signal for the onset of oxidative and heat stress. Recent evidence has accumulated against this concept (Van Bogelen et al., 1987), although a significant overlap exists between peroxide and heat-shock-inducible proteins in Sal. typhimurium (Morgan et al., 1986) but less so in E. coli (Van Bogelen et al., 1987).

In this report, we describe the response of aerobic and anaerobic $S$. cerevisiae cells to oxidative stress, induced by $\mathrm{H}_{2} \mathrm{O}_{2}$, and temperature shifts. Intrinsic resistance to heat stress $\left(52{ }^{\circ} \mathrm{C}, 5 \mathrm{~min}\right.$; Fig. 2) and oxidative stress (20 $\mathrm{mM} \mathrm{H}_{2} \mathrm{O}_{2}, 15 \mathrm{~min}$; Fig. 5) varied during the growth phase in batch culture, with cells in the exponential growth phase much more sensitive than cells in the stationary phase. It is well documented that yeast cells in the stationary phase are intrinsically more resistant to temperature stress as compared to cells in the exponential phase (Schenberg-Frascino \& Moustacchi, 1972; Parry et al., 1976; Walton et al., 1979). Furthermore, in the case of Bacillus subtilis, it was reported that cells in the stationary phase were remarkably resistant to high levels $(10 \mathrm{mM})$ of $\mathrm{H}_{2} \mathrm{O}_{2}$ (Murphy et al., 1987). The present study extends these observations to include cellular physiology and membrane composition.

Early studies on E. coli by Overath et al. (1970) showed that $C_{18: 1}$-supplemented cells could grow at temperatures up to $45^{\circ} \mathrm{C}$, whereas $C_{18: 3^{-s u p p l e m e n t e d ~ c e l l s ~ w e r e ~}}$ unable to grow at temperatures about $40^{\circ} \mathrm{C}$. In later studies, Yatvin (1977) reported that $C_{18: 1^{-}}$supplemented $E$. coli cells were more thermoresistant than $\mathrm{C}_{18: 3^{-}}$ supplemented cells. It is clear from the present study that the membrane lipid composition, while important, is not the only parameter affecting thermotolerance and oxytolerance. The trend in anaerobically grown yeast cells was for a decrease in stress tolerance with increasing unsaturation of membrane fatty acids, which is in keeping with the previous observations on $E$. coli. On the other hand, aerobically grown cells enriched in monounsaturated fatty acids (for $S$. cerevisiae, characteristically $40 \% \mathrm{C}_{16: 1}$ and $38 \% \mathrm{C}_{18: 1}$ ) were the most stress tolerant under all experimental conditions.

We are led to suggest, therefore, that the metabolic state of the cells may also be an important factor in stress tolerance. This conclusion is in keeping with recent studies on stress tolerance of yeast cells grown on fermentable and non-fermentable carbon sources (Hou et al., 1991 ; Sanchez et al., 1992; Lewis et al., 1993a; Elliot \& Futcher, 1993). These studies have shown that yeast cells grown on a non-fermentable carbon source and with a high respiratory rate were intrinsically more resistant to heat (Hou et al., 1991; Sanchez et al., 1992; Elliot \& Futcher, 1993) and $\mathrm{H}_{2} \mathrm{O}_{2}$ (Hou et al., 1991) than the corresponding cells grown on a fermentable carbon source.

It should be pointed out that the relationship of intrinsic or induced tolerance and growth phase with respect to studies on stress tolerance is crucial and is one which has not been adequately addressed in the past. For example, for yeast cells growing on glucose as a carbon source, the term stationary phase is generally taken to mean the point in the growth curve corresponding to exhaustion of glucose. For the purposes of the present studies we have adopted this definition for stationary phase. However, many yeasts are capable of further growth on ethanol, the end-product of glucose fermentation. In this case, the point corresponding to glucose exhaustion should be more precisely termed diauxic lag phase. This is followed by respiratory growth on ethanol (respiratory phase), and the point at which ethanol is exhausted is true stationary phase. Recent studies from this laboratory have demonstrated marked differences during growth in the response of yeast cells to a wide range of environmental stresses including heat and freeze-thaw (Lewis et al., 1993b).

In the context of the present study, anaerobically grown cells were essentially obtaining energy via glycolysis, whereas the aerobically grown cells, although subject to catabolite repression, were obtaining energy via glycolysis and respiration. In keeping with the above discussion, aerobically grown cells were intrinsically more stress tolerant than anaerobically grown cells. This may in part be due also to induction of antioxidant enzyme systems, which is the subject of further study in our laboratory.

Higher levels of tolerance to heat stress could be induced by prior heat shock $\left(37^{\circ} \mathrm{C}, 30 \mathrm{~min}\right)$ in aerobic and anaerobic cells (Fig. 2). While induced thermotolerance has been reported previously for aerobic yeast cells (reviewed by Watson, 1990), the demonstration that thermotolerance may be induced in anaerobically grown $S$. cerevisiae is a novel finding. Induced thermotolerance followed the same trends as for intrinsic tolerance, in that tolerance increased as cells grew into stationary phase, and aerobic cells were the most resistant, followed in order by anaerobic unsupplemented, $C_{18: 1^{-}}$-supplemented and $\mathrm{C}_{18: 3}$-supplemented anaerobic cells.

Similar trends were noted for induction of tolerance to $\mathrm{H}_{2} \mathrm{O}_{2}$ stress (Fig. 5). Increased tolerance to $20 \mathrm{mM} \mathrm{H}_{2} \mathrm{O}_{2}$ could be induced in all cells by a mild $\mathrm{H}_{2} \mathrm{O}_{2}$ shock $(0.1 \mathrm{mM}, 30 \mathrm{~min})$. The induced tolerance was also growth-phase dependent. It is interesting to note that induced tolerance in anaerobic unsupplemented and $\mathrm{C}_{18: 1^{-}}$ supplemented cells approached the level of induced tolerance of aerobic cells, with $\mathrm{C}_{18: 3^{-}}$-supplemented cells again the most sensitive. That a prior mild peroxide shock should lead to peroxide tolerance has been demonstrated in this report for $S$. cerevisiae and also recently by others (Collinson \& Dawes, 1992; Jamieson, 1992). Similarly, in $N$. crassa, pretreatment with sublethal doses of $\mathrm{H}_{2} \mathrm{O}_{2}$ induces tolerance to lethal doses (Kapoor et al., 1990). It is noteworthy that in E. coli (Demple \& Halbrook, 1983; 
Christman et al., 1985), Sal. typhimurium (Christman et al., 1985; Winquist et al., 1984) and B. subtilis (Murphy et al., 1987 ), exposure of cells to mild peroxide stress induces tolerance to high levels of peroxide.

The relationship between tolerance to heat and $\mathrm{H}_{2} \mathrm{O}_{2}$ was also examined. While a mild heat shock was found to induce tolerance against both lethal temperature and $\mathrm{H}_{2} \mathrm{O}_{2}$ challenges (Fig. 6), pretreatment with low levels of $\mathrm{H}_{2} \mathrm{O}_{2}$ induced tolerance against a lethal level of $\mathrm{H}_{2} \mathrm{O}_{2}$ but not a lethal temperature challenge. Studies by us (Steels $e t$ al., 1991; this report) and others (Collinson \& Dawes, 1992; Jamieson, 1992) have shown heat-shock acquisition of peroxide tolerance in $S$. cerevisiae, as has been found for $N$. crassa (Kapoor \& Lewis, 1987a). However, Christman et al. (1985) reported that in Sal. typhimurium a prior heat shock did not result in peroxide tolerance. Interestingly, in $N$. crassa, mild peroxide shock also induces thermotolerance (Kapoor et al., 1990). By contrast, this report and that of Collinson \& Dawes (1992) showed that yeast cells do not acquire thermotolerance following a mild peroxide shock, although Jamieson (1992) recently reported a small increase in thermotolerance. In Sal. typhimurium, a mild peroxide shock was found to induce thermotolerance (Christman et al., 1985).

Tolerance to the heat and oxidative stresses in S. cerevisiae is related, as evidenced by the protection against oxidative stress by heat shock. It is possible that mild oxidative shock induces only a subset of responses induced by heat shock, and therefore is not protective against heat stress. This is consistent with our finding that peroxide shock did not induce synthesis of heat-shock proteins (Steels, unpublished observation). While Collinson \& Dawes (1992) found that $\mathrm{H}_{2} \mathrm{O}_{2}$ induced some proteins, none of the classical heat-shock proteins were induced. In eukaryotic micro-organisms, there are few data concerning the function of stress proteins in oxidative stress. In $N$. crassa, the hsp 70 group of stress proteins includes at least seven polypeptides (Kapoor \& Lewis, 1987b), two of which are constitutively synthesized and elevated in response to a heat shock and another two which are apparently induced only on a heat shock or on $\mathrm{H}_{2} \mathrm{O}_{2}$ treatment of cells. Exposure of $N$. crassa cells to low levels of $\mathrm{H}_{2} \mathrm{O}_{2}$ for $1 \mathrm{~h}$ induced the synthesis of a subset of hsp70 stress proteins as well as a specific oxidative responsive protein, designated OSP80 (Kapoor \& Lewis, 1987b). In addition, it was demonstrated in $N$. crassa that heat shock induced the synthesis of peroxidase activity (Kapoor \& Lewis, 1987a).

In the present study, increased levels of TBARS were observed, indicative of malondialdehyde formation, in yeast cells subjected to a heat or oxidative stress (Table 1). Although the TBA test is not specific to malondialdehyde and its derivatives, it is an approximate measure of lipid oxidation and has been widely used as an index of lipid damage. In cells grown anaerobically and stressed with $\mathrm{H}_{2} \mathrm{O}_{2}$, the amount of TBARS correlated with the degree of membrane lipid unsaturation. Cell survival correlated inversely with levels of TBARS. When cells were exposed to a mild heat shock or $\mathrm{H}_{2} \mathrm{O}_{2}$ shock, levels of TBARS increased (Table 2). When this was followed by a lethal stress, levels of TBARS increased to levels similar to those produced by the stress alone, although higher tolerance was induced. This indicates that although cellular damage was evident, protective or repair mechanisms were induced to increase survival of the stresses. Damage limitation seems to have occurred, since the shock/stress levels of TBARS were lower than the sum of individual shock and stress components (Table 2). We are tempted to conclude that cells subjected to heat or oxidative stress may share a common mechanism of induced synthesis of oxygen-derived free radicals, leading to membrane lipid damage. The more unsaturated the membrane lipids the higher the degree of lipid and cell damage.

This hypothesis may be supported by observations about the temperature dependence of the solubility of oxygen in aqueous and membrane compartments. Increasing the temperature from $25^{\circ} \mathrm{C}$ decreases the solubility of oxygen in media and cells. Using the equations provided by Hitchman (1978) it was calculated that in our experiments there would be a decrease in oxygen solubility of $21 \%$ from $25^{\circ} \mathrm{C}(211 \mathrm{mM} \mathrm{O})$ to $37{ }^{\circ} \mathrm{C}(167 \mathrm{mM})$, and a $47 \%$ decrease at $52^{\circ} \mathrm{C}(111 \mathrm{mM})$. In contrast to the situation in aqueous solution, Smotkin et al. (1991) found that in liquid-crystalline phase phospholipid vesicles, oxygen solubility was about four times that in aqueous solution, and that as the temperature rose from $25^{\circ} \mathrm{C}$ to $40^{\circ} \mathrm{C}$, partitioning of oxygen into membranes increased. Thus as the temperature increases, oxygen solubility in aqueous environments decreases, while relative solubility in membranes increases. This may lead to localized high concentrations of oxygen within membranes, which may correlate with a rapid rise in reactive oxygen-derived species as a result of temperature upshifts. This analysis is somewhat simplified and other factors must be taken into account, for example that oxygen gradients may exist within cells (Halliwell \& Gutteridge, 1989).

Thus the changes in oxygen solubility noted above provide an attractive explanation for increased free-radical damage as a result of heat shock under aerobic conditions. In addition to generating local high concentrations of oxygen, increased temperatures themselves could be expected to lead to increased free-radical generation. The latter temperature effect would be especially important in cells grown under low oxygen tensions. The common features of cellular responses to heat and oxidative stress may therefore be due to common mechanisms of damage caused by free radicals.

\section{ACKNOWLEDGEMENTS}

This work was supported by grants from the Australian Research Council and internal research grants from the University of New England. E. L.S. was supported by an Australian Postgraduate Research Scholarship.

\section{REFERENCES}

Bochner, B. R., Lee, P. C., Wilson, S. W., Cutler, C. W. \& Ames, B. N. (1984). AppppA and related adenylated nucleotides are synthesized as a consequence of oxidation stress. Cell 37, 225-232. 
Bradford, M. M. (1976). A rapid and sensitive method for the quantitation of microgram quantities of protein utilizing the principle of protein-dye binding. Anal Biochem 72, 248-254.

Christman, M. F., Morgan, R. W., Jacobson, F. S. \& Ames, B. N. (1985). Positive control of a regulon for defenses against oxidative stress and some heat shock proteins in Salmonella typhimurium. Cell 41, 753-762.

Collinson, L. P. \& Dawes, I. W. (1992). Inducibility of the response of yeast cells to peroxide stress. J Gen Microbiol 138, 329-335.

Demple, B. \& Halbrook, J. (1983). Inducible repair of oxidative DNA damage in Escherichia coli. Nature 304, 466-468.

Elliott, B. \& Futcher, B. (1993). Stress resistance of yeast cells is largely independent of cell cycle phase. Yeast 9, 33-42.

Farr, S. B. \& Kogoma, T. (1991). Oxidative stress responses in Escherichia coli and Salmonella typhimurium. Microbiol Rev 55, 561-585.

Halliwell, B. (1987). Oxidants and human disease: some new concepts. F ASEB Journal 1, 358-364.

Halliwell, B. \& Grootveld, M. (1987). The measurement of free radical reactions in humans. Some thoughts for future experimentation. FEBS Lett 213, 9-14.

Halliwell, B. \& Gutteridge, J. M. C. (1989). Free Radicals in Biology and Medicine, 2nd edn. Oxford: Clarendon Press.

Hitchman, M. L. (1978). Measurement of dissolved oxygen. Chem Anal 49, 19-27.

Hou, Y., Learmonth, R. P. \& Watson, K. (1991). Intrinsic and induced resistance to oxidative and heat stress is dependent on mitochondrial function. Proc Aust Soc Biochem \& Mol Biol 23, SP52.

Jain, S. (1988). Evidence for lipid peroxidation during in vivo aging of human erythrocytes. Biocbim Biophys Acta 937, 201-210.

Jamieson, D. K. (1992). Saccharomyces cerevisiae has distinct adaptive responses to both hydrogen peroxide and menadione. $J$ Bacteriol 174, 6678-6681.

Kapoor, M. \& Lewis, J. (1987a). Heat shock induces peroxidase activity in Neurospora crassa and confers tolerance towards oxidative stress. Biochem Biophys Res Commun 147, 904-910.

Kapoor, M. \& Lewis, J. (1987b). Alteration of the protein synthesis pattern in Neurospora crassa cells by hyperthermal and oxidative stress. Can J Microbiol 33, 162-168.

Kapoor, M., Screenivasan, G. M., Goel, N. \& Lewis, J. (1990). Development of thermotolerance in Neurospora crassa by heat shock and other stresses eliciting peroxidase induction. $J$ Bacteriol 172, 2798-2801.

Lee, P. C., Bochner, B. R. \& Ames, B. N. (1983). AppppA, heatshock stress and cell oxidation. Proc Natl Acad Sci USA 80 , 7496-7500.

Lewis, J. G., Learmonth, R. P. \& Watson, K. (1993a). The role of growth phase and ethanol in freeze-thaw stress resistance of Saccharomyces cerevisiae. Appl Environ Microbiol 59, 1065-1071.

Lewis, J. G., Northcott, C. J., Learmonth, R. P., Attfield, P. V. \& Watson, K. (1993b). The need for consistent nomenclature and assessment of growth phases in diauxic cultures of Saccharomyces cerevisiae. J Gen Microbiol 139, 835-839.
Morgan, R. W., Christman, M. F., Jacobson, F. S., Storz, G. \& Ames, B. N. (1986). Hydrogen peroxide inducible proteins in Salmonella typhimurium overlap with heat shock and other stress proteins. Proc Natl Acad Sci US A 83, 8059-8063.

Murphy, P., Dowds, B. C. A., McConnell, D. J. \& Devine, K. M. (1987). Oxidative stress and growth temperature in Bacillus subtilis. J Bacteriol 169, 5766-5770.

Overath, P., Schairer, H. U. \& Stoffel, W. (1970). Correlation of in vivo and in vitro phase transitions of membrane lipids in Escherichia coli. Proc Natl Acad Sci US A 67, 606-612.

Parry, J. M., Davies, P. J. \& Evans, W. E. (1976). The effects of 'cell age' upon the lethal effects of physical and chemical mutagens in the yeast, Saccharomyces cerevisiae. Mol \& Gen Genet 146, 27-35.

Sanchez, Y., Taulien, J., Borkovich, K. A. \& Lindquist, S. (1992). Hsp104 is required for tolerance to many forms of stress. EMBO J 11, 2357-2364.

Schenberg-Frascino, A. \& Moustacchi, E. (1972). Lethal and mutagenic effects of elevated temperature on haploid yeast. I. Variations in sensitivity during the cell cycle. Mol \& Gen Genet 115, 243-257.

Sies, H. (1986). Biochemistry of oxidative stress. Angew Chem Int Ed Engl 25, 1058-1071.

Smotkin, E. S., Moy, F. T. \& Plachy, W. Z. (1991). Dioxygen solubility in aqueous phosphatidyl choline dispersions. Biochim Biopbys Acta 1061, 33-38.

Steels, E. L., Learmonth, R. P. \& Watson, K. (1991). Heat and oxidative stress as a function of membrane lipid composition in yeast. Proc Aust Soc Biochem \& Mol Biol 23, C46.

Van Bogelen, R. A., Kelley, P. M. \& Neidhardt, F. C. (1987). Differential induction of heat shock, SOS and oxidative stress regulons and accumulation of nucleotides in Escherichia coli. $J$ Bacteriol 169, 26-32.

Walton, E. F., Fintan, E., Carter, B. L. A. \& Pringle, J. R. (1979). An enrichment method for temperature sensitive and auxotrophic mutants of yeast. Mol \& Gen Genet 171, 111-114.

Watson, K. (1984). Membrane lipid adaptation in yeasts. In Membrane Fluidity, pp. 517-542. Edited by M. Kates \& L. A. Manson. New York: Plenum.

Watson, K. (1990). Microbial stress proteins. Adv Microb Pbysiol 31, 183-223.

Watson, K. \& Rose, A. H. (1980). Fatty-acyl composition of the lipids in Saccharomyces cerevisiae grown aerobically or anaerobically in media containing different fatty acids. $J$ Gen Microbiol 117, 225-233.

Winquist, L., Rannug, U., Rannug, A. \& Ramel, C. (1984). Protection from toxic and mutagenic effects of hydrogen peroxide by catalase induction in Salmonella typhimurium. Mutat Res 141, 145-147.

Yatvin, M. B. (1977). The influence of membrane lipid composition and procaine on hyperthermic death of cells. Int J Radiat Biol 32, 513-521.

Received 28 June 1993; revised 15 September 1993; accepted 4 October 1993. 